\title{
The Prevalance of HBV, HCV and HIV Among Healthcare Workers in a Dental Hospital
}

\author{
Diș Hastanesi Çalıșanlarında HBV, HCV ve HIV Prevalansı
}

\author{
Şükran KÖSE, Sabri ATALAY, Feyza ARSLAN, Gürsel ERSAN
}

Izmir Tepecik Training and Research Hospital, Izmir, Turkey

\begin{abstract}
Objective: As healthcare professionals are exposed to infected blood samples, they are at increased risks of exposure to many infectious agents. The aim of the study was to investigate the seroprevalence of hepatitis B virus (HBV), hepatitis C virus (HCV) and human immunodeficiency virus (HIV) infections among healthcare professionals and hospital staff at a dental hospital.

Materials and Methods: A face to face questionnaire was carried out and $\mathrm{HBsAg}$, anti-HBs, anti-HCV, and HIV antibody (anti-HIV) markers were analyzed from blood samples of 174 healthcare professionals at a dental hospital in Izmir via ELISA (Abbott, Wiesbaden, Germany) test.

Results: None of the participants was positive for $\mathrm{HBsAg}$, and 136 participants $(78.1 \%)$ had positive anti-HBs. Of the anti-HBs-positive participants, 12 (8.8\%) were positive for anti-HBc lgG. Anti-HCV positivity was detected in two participants, and the test results were confirmed with HCV RNA assay. HBV vaccination was recommended for participants unexposed to hepatitis B. Anti-HIV 1-2 was negative in all participants.

Conclusion: In our study, immunity rates against HBV was high. This high rate was the result of high vaccination rates among the healthcare professionals. HCV prevalence among the healthcare professionals was similar to that in the general population. Hospital workers should be screened for HBV, HCV and HIV; individuals without HBV vaccination should be vaccinated, and all hospital personnel should receive training programs about the transmission of blood-borne infections. Training programs may prevent the possible infections. (Viral Hepatitis Journal 2014; 20(2): 75-77)

Key words: Hepatitis, HIV, healthcare professionals
\end{abstract}

\section{ÖZET}

Amaç: Sağlık sektöründe çalışan kişilerin enfekte kan ile maruziyeti olduğu için birçok enfeksiyöz etken açııından yüksek risk altındadır. Bu çalışmada diş hastanesi çalışanlarında hepatit $B$ virüs (HBV), hepatit C virüs (HCV) ve HIV seropozitifliğinin araştıııması amaçlanmışırı.

Gereç ve Yöntemler: Izmir ilinde yer alan diş hastanesinde görev yapan 174 sağlık çalışanı ile yüz yüze görüşülerek anket doldurulmuş ve alınan kan örneklerinde ELISA (Abbott, Wiesbaden, Almanya) ile HBsAg, Anti HBs, anti HBc lgG, anti HCV ve anti HIV 1-2 araştırılmıştır.

Bulgular: Çalışmaya alınan 174 kişinin hiçbirinde HBsAg pozitifliği saptanmamıştır. Yüz otuz altı kişide $(\% 78,1)$ Anti HBs pozitif olarak saptanmıştır. Anti HBs pozitif olan bireylerin 12 'sinde $(\% 8,8)$ Anti HBc lgG pozitif olarak belirlenmiştir. Anti HCV pozitifliği iki olguda $(\% 1,1)$ belirlenmiş ve test sonucu HCV RNA ile doğrulanmıştır. Hepatit B ile karşılaşmayan kişiler aşılanma için yönlendirilmiştir. Anti-HIV 1-2 tüm kişilerde negatif olarak saptanmıştır.

Sonuç: Çalışmamızda HBV'ye karşı bağışıklık oranları yüksektir. Bu yüksek oran sağık personeli arasında aşılama oranlarının yüksek olmasına bağlıdır. HCV prevalansı genel popülasyonla benzer bulunmuştur. Hastane çalışanlarının HBV, HCV ve HIV açısından taranması, HBV aşısı olmayan personelin aşılanması ve tüm hastane çalışanlarına kan yoluyla bulaşan enfeksiyonlar hakkında eğitim verilmesi gerekmektedir. (Viral Hepatit Dergisi 2014; 20(2): 75-77)

Anahtar Kelimeler: Hepatit, HIV, sağılı çalışanları

\section{Introduction}

Nearly 2 billion subjects are infected by hepatitis B virus (HBV) in the world (1). In a study, it was determined that the rate of carrier state among healthcare professionals was 1.5 folds higher than in the normal population (2). Nearly $1 / 3$ of the worlds population, namely 170 million subjects, were infected by hepatitis $\mathrm{C}$ virus (HCV) (3). In our country, the prevalence of HCV infection has been reported to be varied between $1 \%-2 \%$ and $4 \%$ in studies conducted on some groups; anti-HCV positivity rate was detected to be $0 \%-1.2 \%$ among healthcare professionals $(4,5)$. Healthcare professionals have high risk for transmission of blood-borne pathogens, especially HBV and HCV. These risks are related with exposure to blood or blood products; wounds by infected sharp and penetrating tools; age and race (6). According to year 2013 national data of the Ministry of Health, there are 6802 registered HIV-positive individuals in Turkey. 
The aim of the present study was to investigate the seropositivity rates for HBV, anti-HBs, anti-HBc IgG, anti-HCV, and anti-HIV 1-2 among healthcare professionals at the Alsancak Dental Hospital.

\section{Material and Methods}

A total of 174 subjects, including 43 physicians, 20 nurses, 33 technicians and 35 workers from a cleaning company, 43 staff members (officials, secretaries, kitchen personnel, and security officers), who were working at the Alsancak Dental Hospital, were included in the study; 94 (54\%) were females and 80 (46\%) were males. Written informed consent was obtained from all participants before sample testing. Tests were performed in the same day that blood samples were obtained and after serums were separated. Positivity for HBsAg, anti-HBs, anti-HBc lgG, anti-HCV, and anti-HIV 1-2 was investigated in serums using ELISA method.

\section{Results}

A total of 174 subjects were included in the study which was conducted at the Izmir Alsancak Dental Hospital in March 2012. The mean age of the participants was 37.4 years, and HBsAg positivity was determined in none of the subjects. Anti-HBs was detected as positive in $136(78.1 \%)$ subjects, and $12(8.8 \%)$ of anti HBs-positive subjects had positive anti-HBc $\operatorname{lgG}$, and these subjects were evaluated as naturally immune. Anti-HCV positivity was detected in two cases $(1.1 \%)$, and the test results were confirmed by HCV RNA. Anti-HIV 1-2 was detected as negative in all staff members. Subjects with negative anti-HBs were scheduled for the vaccination program. Vaccination history of subjects with positive anti-HBs was investigated. Subjects with positive anti$\mathrm{HCV}$ were referred to outpatient clinics of infectious diseases for treatment and follow up.

In the present study, anti-HBs was detected positive in $48.8 \%$ of physicians, $100 \%$ of nurses, $52.5 \%$ of technicians, $45.7 \%$ of cleaning personnel, and $46.5 \%$ of other personnel. It was found that $9.3 \%$ of physicians, $5 \%$ of nurses, $3 \%$ of technicians, $57 \%$ of cleaning personnel, and $9.3 \%$ of subjects in other occupations had natural immunity. Vaccination rates against HBV were determined as $90.7 \%$ among physicians, $85 \%$ among nurses, $87.8 \%$ among technicians, $65.7 \%$ among cleaning personnel, and $32.6 \%$ among other personnel. The vaccination rate was the highest among physicians, whereas lowest among other occupations. There was a statistically significantly difference in vaccination rates between the occupational groups $(p<0.001)$.

Familial history of jaundice and operation history were determined as the risk factors among subjects with positive antiHCV. It was detected that one of the subjects with positive antiHCV had natural immunity against HBV.

\section{Discussion}

It is known that there is a close relationship between transmission routes of HBV infection and endemicity. It has been reported that the prevalence of hepatitis $B$ increased as moving from the Western to the Eastern part of Turkey; the prevalence rates were determined high in Elazığ and Van, and positivity rate of HBsAg reached to $14.5 \%$ in Gaziantep (7). When compared to the developed countries, endemicity rate was determined higher in our country, and the difference in HBV prevalence was so small between the risk groups and normal population.

In a study comparing dentists, who were members of the group at risk for with HBV infection, with individuals from the normal population, the life-long HBV risk for dentists was determined to be $13 \%-28 \%$ and for the normal population as $5.0 \%$ (8). According to data from WHO, 304.000 healthcare professionals have been traumatized annually in Europe by HBV contaminated tools. Ziraba et al. (9) reported that the rate was $8.1 \%$ among healthcare personnel. It has been reported in the studies from Turkey that HBsAg positivity rates were $1.7 \%$ among healthcare professionals in Düzce Atatürk Governmental Hospital (10), and $1.0 \%$ in Kayseri Obstetrics and Child Hospital (11). HBsAg positivity was not detected in the present study. The leading causes may be explained by the high rate of hepatitis $B$ vaccination among the hospital professionals, and preventive measures taken to prevent HBV transmission at working environment.

When studies from all over the world investigating $\mathrm{HCV}$ prevalence among healthcare professionals were reviewed, $\mathrm{HCV}$ prevalence in Egypt was reported as $0.31 \%$ in a study conducted on 717 healthcare professionals (12). In a study conducted in the Netherlands, only one subject $(0.14 \%)$ among 729 healthcare professionals was confirmed to be positive for anti-HCV and positive for HCV RNA (13). Inci et al. reported that anti-HCV positivity rate among healthcare professionals in our country was $0.34 \%$ (11). Consistent with these results, anti-HCV positivity was determined as $1.1 \%$ among healthcare professionals in the present study.

The number of HIV-infected individuals is nearly 34.2 million in the world, and 6802 in Turkey. In a study conducted by Güzelant et al., HIV seropositivity was not found in blood donors, and dentalcare workers (14). Inci et al. did not report HIV positivity among healthcare professionals in their study (11). Similar to the national data, no HIV positivity was detected in the present study. However, there are cases that infected healthcare personnel contaminated healthy patients with HBV and HIV. When contamination routes from healthcare professionals to patients are investigated, cases with HIV contamination from dentists, surgeons, and nurses to patients have been reported in the world (15). From this point of view, although HIV positivity has not been detected among healthcare professionals in the previous studies, screening should be continued regularly.

Although surgeons, dentists, and nurses are the most significant risk groups in infection contamination among healthcare professionals, all other personnel working at the hospitals carry similar risks. Individuals working in the healthcare field should be informed about HAV, HBV, HCV, and HIV contaminations. Considering all patients as risky groups, the necessary preventive measures should be applied for all healthcare professionals before contacting blood and body fluids of patients.

\section{Conflict of interest: None declared.}

\section{References}

1. Bosch FX, Ribes J, Cleries R, Diaz M. Epidemiology of hepatocellular carcinoma. Clin Liver Dis. 2005; 9: 191-211. 
2. Dientstag JL, Ryan DM. Occupational exposure to hepatitis $B$ virus in hospital personnel: infection or immunization? Am J Epidemiol 1982; 115(1): 26-39.

3. Poynard T, Yuen MF, Ratziu V, Lai CL. Viral hepatitis C. Lancet. 2003; 362: 2095-100.

4. Çakaloğlu Y. Hepatit B ulusal uzlaşma toplantı metinleri. 2005; 99

5. Ergönül Ö. Ankara Numune Eğitim ve Araştırma Hastanesinde Sağlık çalışanlarında hepatit B infeksiyonu. Viral Hepatit Dergisi. 2001; 2: 327-9.

6. Mıstık R. Türkiye'de viral hepatit epidemiyolojisi - Yayınların irdelenmesi. Içinde: Tabak F, Balık I, Tekeli E, (editörler.), Viral Hepatit 2007. Ankara: Viral Hepatitle Savaşım Derneği. 2007: 10-50.

7. Akca G. Diş Hekimliğinde Kan Yoluyla Bulaşan Viral Infeksiyonlar ve Önemi. Hastane Infeksiyonları Dergisi. 2008; 12: 5-10.

8. Puro V, De Carli G, Cicalini S, Soldani F, Balslev U, Begovac $\mathrm{J}$, et al. European recommendations for the management of healthcare workers occupationally exposed to hepatitis B virus and hepatitis C virus. Euro Surveill. 2005; 10: 260-4.

9. Ziraba AK, Bwogi J, Namale A, Wainaina CW, Mayanja-Kizza H. Sero-prevalence and risk factors for hepatitis $B$ virus infection among health care workers in a tertiary hospital in Uganda. BMC Infect Dis. 2010; 10: 191.
10. Öksüz Ş, Yıldırım M, Özaydın Ç, Şahin I, Arabacı H, Gemici G. Bir devlet hastanesi çalışanlarında HBV ve HCV seroprevalansının araştırılması. ANKEM Derg. 2009; 23(1): 30-3.

11. Inci $M$, Aksebzeci $A$, Yağmur G, Kartal B, Emiroğlu M, Erdem Y. Hastane çalışanlarında HBV, HCV ve HIV seropozitifliğinin araştırılması. Türk Hijyen ve Deneysel Biyoloji dergisi. 2009; 66(2): 59-66.

12. Abdelwahab SF, Hashem M, Galal I, Sobhy M, Abdel-Ghaffar TS, Galal G, et al. Incidence of hepatitis $C$ virus infection among Egyptian healthcare workers at high risk of infection. J Clin Virol. 2013; 57: 24-8.

13. Zaaijer HL, Appelman P, Frijstein G, Hepatitis C virus infection among transmission-prone medical personnel. Eur $\mathrm{J}$ Clin Microbiol Infect Dis. 2012; 31(7): 1473-7.

14. Güzelant A, Kurtoğlu MG, Kaya M, Keşli R, Baysal B. Kan vericilerinde ve bir ağız-diş sağlığı merkezi çalışanlarında hepatit $B$, hepatit $C$ ve HIV seroprevalansı ile vericilerde risk faktörlerinin araştırılması. Infeksiyon Derg. 2008; 22(4): 189-95.

15. Bosch X. Second case of doctor-to-patient HIV transmission. Lancet Infect Dis.2003; 3(5): 261. 